\title{
Is there still a public service ethos?
}

Link to publication record in Manchester Research Explorer

\section{Citation for published version (APA):}

John, P., Johnson, M., Park, A. (Ed.), Curtice, J. (Ed.), Thomson, K. (Ed.), Phillips, M. (Ed.), \& Clery, E. (Ed.) (2008). Is there still a public service ethos? In British Social Attitudes: the 24th Report (pp. 105-125). Sage Publications Ltd.

\section{Published in:}

British Social Attitudes: the 24th Report

\section{Citing this paper}

Please note that where the full-text provided on Manchester Research Explorer is the Author Accepted Manuscript or Proof version this may differ from the final Published version. If citing, it is advised that you check and use the publisher's definitive version.

\section{General rights}

Copyright and moral rights for the publications made accessible in the Research Explorer are retained by the authors and/or other copyright owners and it is a condition of accessing publications that users recognise and abide by the legal requirements associated with these rights.

\section{Takedown policy}

If you believe that this document breaches copyright please refer to the University of Manchester's Takedown Procedures [http://man.ac.uk/04Y6Bo] or contact uml.scholarlycommunications@manchester.ac.uk providing relevant details, so we can investigate your claim.

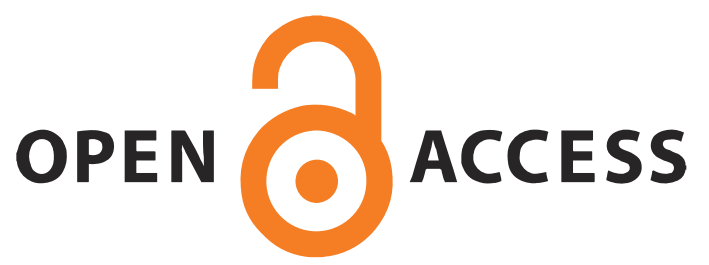


Park, A., Curtice, J., Thomson, K., Phillips, M., Johnson, M. and Clery, E. (eds.) (2008), British Social Attitudes: the $24^{\text {th }}$ Report, London: Sage

\title{
5 Is there still a public service ethos?
}

\author{
Peter John and Mark Johnson*
}

For many people, the choice between working in the public and private sector is a fundamental one. On the downside, public sector pay is on average lower for equivalent jobs than in the private sector, and public sector employees may feel constrained by a larger number of rules and regulations (Boyne, 2002; Allington and Morgan, 2003). But on the upside, the public sector may have one unique advantage to offer: the chance to do a socially useful job. Public sector bodies are supposed to advance outcomes that societies care about. Such beliefs and values are often thought to be shared by those who work there - in contrast with the supposedly more selfish outlooks of those who are employed in the private sector whose individual rewards tend to be tied to profits and sales. If so, this publicly orientated set of values may help compensate for lower levels of remuneration and generally worse working conditions in the public sector.

This so-called 'public service ethos' is valued by policymakers. The cynical commentator may say that it can help keep wages down. But even those who do not take that position would tend to agree that a motivated staff, who are keen to do their most for the public realm, can help to ensure that the large spending increases of recent years translate into improved public policy outcomes. Workers in the public sector face considerable challenges, whether it is teaching children in an urban school or nursing walk-in cases at an NHS Accident and Emergency clinic. These are the kinds of jobs that cannot be done by people who are just there for the extrinsic benefits and financial rewards. They need a public service ethos for employees to engage with this demanding but intrinsically rewarding work.

Talking about the public service ethos is also a way of recognising the wider contribution these workers make to society in the number of unpaid hours and extra effort they put in beyond what is laid down in their contracts. It provides an answer to the populist and right-wing critique of the public sector as being less efficient because there is no profit motive driving productivity. Another

* Peter John is the Hallsworth Chair of Governance at the University of Manchester. Mark Johnson was formerly a Senior Researcher at the National Centre for Social Research and Co-Director of the British Social Attitudes survey series. 
benefit is supposed to be the ability of the civil service to attract some of the brightest graduates away from more lucrative city careers to take up careers in the civil service. So it is no surprise that decision makers and opinion leaders think the public service ethos should be cultivated for the benefit of society as a whole (see Public Administration Committee, 2002).

There has been a lot of academic attention paid to the public service ethos in recent years. Survey and case study evidence suggests that those working in the public sector have a more altruistic motivation than those in the private sector (Crewson, 1995; Pratchett and Wingfield, 1996; Steele, 1999; Houston, 2000; Public Services Productivity Panel, 2002; Norris, 2003; Buelens and Broeck, 2007). Many researchers regard the public service ethos as an attachment to the intrinsic elements of a job, which includes feelings of accomplishment and selfworth. But here we offer a simpler definition of wanting to work for the public interest, which is similar to the approach of Rainey and Wittmer (Rainey, 1982; Wittmer; 1991). The advantage of this definition is that it focuses on the key purpose of the public sector and how its mission can become part of workers' own views and motivations.

One important issue addressed by previous research is whether the public service ethos is a result of self-selection (possibly as a result of certain educational pathways) or post-entry socialisation. While neither approach necessarily undermines the altruistic nature of the values, the latter seems to be more about how organisational power shapes values, particularly if these are needed for career advancement. Linked to this is the importance of hierarchy. Do those in managerial grades have more public service ethos than others? If you are at the bottom of the pile, like a manual worker in the National Health Service, are you more interested in pay and conditions than in doing public good? But, it seems this is not the case: many studies show similarity between the public and private sectors among those at managerial grades (Rainey and Bozeman, 2000; Buelens and Broeck, 2007).

Another unresolved question is whether it is working in the public sector per se or the kind of job that is important. This is particularly hard to investigate because some jobs exist only in the public sector (e.g. social work, university teaching) or are mainly in it (e.g. doctors and nurses). Too few studies compare the same kind of employees in both sectors, but Buelens and Broeck conclude that it is job content rather than working in the public sector itself that counts, which suggests that public sector ownership is not a necessary condition for a public service ethos (Buelens and Broeck, 2007).

The academic literature also focuses on the different bases of the public service ethos. Gender is a particularly interesting example because of the large number of women employed in the public sector (DeHart-Davis et al., 2006). Less discussed are age or cohort effects but these can be very influential if a particular age group has a different vision for society than the rest (Jurkiewicz and Brown, 1998). This chapter is particularly interested in this dimension to the ethos as it may be a component of how it changes over time.

Many policymakers and commentators think that the public service ethos has declined. Perhaps the public service ethos was a feature of a more collectivist or 
traditional society, reflecting the values of the post-1945 welfare state reforms and their Webbian antecedents. The idea is that the state - and by implication its employees - could be harnessed for public purposes (Plant, 2003). An extreme example of this view was the idea that the coal miners would increase productivity when the mines were transferred from the private to the public sector. Another common argument is that as the institutions of the state are reformed by privatisation, new public management, quasi-markets, contracting out and private finance projects, the public service ethos would weaken, because traditional bureaucracy is no longer the central means of state intervention. It is argued that the public service ethos is in danger of being replaced by self-interested behaviour driven by performance-related pay and sanctions of performance measurement (Public Administration Committee, 2002). The more public sector workers are treated like self-interested actors working for their short-term benefits, the more they might behave like that, a kind of self-fulfilling prophesy (Le Grand, 2003). If the government pushes choice, private sector delivery and commercial forms of management, the public service ethos could be expected to decline. However, bar some limited case study work (Steele, 1999), there is no evidence of this happening.

This chapter hopes to fill some of these gaps in knowledge by, first, finding out if there is a public service ethos in existence in Britain today. Secondly, we examine how and why it has changed over time. Finally, we look at whether a public service ethos does indeed foster job satisfaction as hoped for by politicians and policymakers.

\section{Public or private?}

We begin by looking at the nature of the workforce. In Britain the majority of people are employed by the private rather than public sector. The British Social Attitudes survey asks respondents to choose which of the following four options best represented the type of organisation they worked for:

- Private sector firm or company, including, for example, limited companies and PLCS

- Nationalised industry or public corporation, including, for example, the Post Office and the BBC

- Other public sector employer, including, for example, Central Government, Civil Service, Government Agency, Local authority, Universities, Health Authority, NHS hospitals, NHS Trusts, GP surgeries, Police, Armed forces

- Charity or Voluntary sector, including, for example, charitable companies, churches, trade unions 
In 2005, two-thirds were in the private sector, three per cent in nationalised industry, 27 per cent in the rest of the public sector, and three per cent in the charity or voluntary sector. The analysis that follows combines those working in nationalised industries with those working for any other public sector employers, to represent the public sector. Those working in the charity or voluntary sector are excluded from the analysis.

As well as actually working in the public sector, it is possible to look at preferences for working in different sectors, which gives an idea of how attractive the different kinds of employment are. The survey asked:

Suppose you were working and could choose between different kinds of jobs. Which of the following would you personally choose?

... working in a private business

... working for the government or civil service

Overall, around 51 per cent of working people would opt for a private business, compared to 23 per cent for the government or civil service, with another 24 per cent unable to decide. Naturally there is a strong correlation between the sector in which people work and the sector in which they would like to work. Some 59 per cent of those in the private sector prefer working in a private business, and only 15 per cent would prefer to work for the government or civil service. But what is revealing is that this association is weaker among those in the public sector, with only 44 per cent saying they would prefer working for the government or civil service whilst 29 per cent would prefer working in the private sector.

\section{Is there a public service ethos?}

To what extent can we identify a public service ethos? We begin by looking at how people value the importance of various components of a job. Table 5.1 shows the list of job attributes presented to respondents with the proportion saying that each attribute was "very important" to them personally in a job.

If there is such a thing as a public service ethos, we would expect to see those in the public sector attributing greater importance to "a job that allows someone to help other people" and "a job that is useful to society". We would also expect public sector respondents to value the intrinsic nature of jobs more highly, such as it being "an interesting job" and being able to "work independently".

And the expected difference is there: public sector workers are more likely to value a job that is socially useful and brings intrinsic rewards. There is also some suggestion that private sector workers are more interested in a high income, which tends to confirm the findings of other research in this area 
(Crewson, 1997). However, this difference is not statistically significant with this rather small sample size.

Table 5.1 Important attributes of a job, private and public sector employees, 2005

\begin{tabular}{|c|c|c|c|}
\hline $\begin{array}{l}\% \text { say "very important" to them } \\
\text { personally ... }\end{array}$ & Private sector & Public sector & Difference \\
\hline$\ldots$ a job that is useful to society & 15 & 32 & +17 \\
\hline $\begin{array}{l}\text {... a job that allows someone to help } \\
\text { other people }\end{array}$ & 18 & 27 & +9 \\
\hline $\begin{array}{l}\text {... a job that allows someone to work } \\
\text { independently }\end{array}$ & 15 & 22 & +7 \\
\hline$\ldots$ an interesting job & 46 & 53 & +7 \\
\hline ... job security & 50 & 49 & -1 \\
\hline ... good opportunities for advancement & 24 & 21 & -3 \\
\hline $\begin{array}{l}\ldots \text { a job that allows someone to decide } \\
\text { their times and days of work }\end{array}$ & 14 & 11 & -3 \\
\hline ... high income & 18 & 12 & -6 \\
\hline Base & 507 & 260 & \\
\hline
\end{tabular}

Overall, the differences fit what a public service ethos should look like - public sector workers are more concerned with jobs where they can help other people and which are useful to society. Note, however, that both groups regard job security as being an important feature.

\section{What explains the public service ethos?}

There is good evidence here that something like a public service ethos actually exists. But could the difference simply be a function of the different compositions of the two sectors?

A number of socio-demographic characteristics are associated with working in the public sector. The next table shows the differences across a series of standard demographic variables: public sector employees are more likely to be older, female, trade union members, professionals and to have a degree than private sector employees. These differences all remain statistically significant once the other factors are taken into account in multivariate analysis. Because of the profile of more professional jobs in the public sector, household income is higher on average for public sector employees, despite the fact that equivalent jobs are usually worse paid. (As a result, the difference in household income disappears in multivariate analysis once the other factors are taken into account.) 
Table 5.2 Composition of private and public sector employees, 2005

\begin{tabular}{lccc}
\hline \% of employees & Private sector & Public sector & Difference \\
Men & 51 & 35 & -16 \\
Women & 49 & 65 & +16 \\
$18-34$ & 33 & 20 & -13 \\
$65+$ & 19 & 24 & +5 \\
Professional & 31 & 52 & +21 \\
Routine/semi-routine & 37 & 24 & -13 \\
Degree or higher & 24 & 44 & +20 \\
No qualifications & 27 & 20 & -7 \\
Highest income quartile & 22 & 27 & +5 \\
Lowest income quartile & 27 & 19 & -8 \\
Labour supporter & 41 & 41 & 0 \\
Conservative supporter & 23 & 24 & -1 \\
Trade union member & 11 & 37 & +26 \\
Base & 2404 & 1158 & \\
\hline
\end{tabular}

Could it simply be the case that the public service ethos is nothing to do with the public sector at all, but is instead produced by these different sociodemographic characteristics? We tested for this using multivariate analysis. As shown in the appendix to this chapter, public sector employees remained significantly more likely than private sector employees to say that it is very important to them for a job to help other people and to be useful to society, even after all these other factors are taken into account. It therefore appears that there really is a measurable public service ethos.

\section{Public service ethos under New Labour}

Having established the existence of the public service ethos, the next task is to determine whether it is in decline as predicted by many commentators. As discussed earlier, many have argued that New Labour's increasing use of new management techniques within the public sector, would undermine the public service ethos. We would therefore expect public and private sector employees to have become more similar in their outlook.

It is possible to test this using questions fielded on the British Social Attitudes survey as part of the International Social Survey Programme. There are data from both 1997 and 2005, which, fortuitously, covers most of the period in which Tony Blair was in office - it was his governments, after all, that pushed the use of the private sector in public services. 
Table 5.3 compares attitudes to the importance of social usefulness in a job in 1997 and 2005. As can be seen, the expectation of reduced differences between public and private sector workers is not fulfilled. In fact, quite the reverse is true, as the difference between private sector and public sector workers has actually widened since 1997. In 1997 the differences between people in the two sectors (at five and three percentage points) were not statistically significant. By 2005 these had grown to 17 and nine percentage points respectively.

Table 5.3 Importance of social usefulness in a job, private and public sector employees, 1997 and 2005

\begin{tabular}{|c|c|c|c|c|c|c|}
\hline \multirow[b]{2}{*}{$\begin{array}{l}\text { \% say "very } \\
\text { important" in a } \\
\text { job }\end{array}$} & \multicolumn{3}{|c|}{1997} & \multicolumn{3}{|c|}{2005} \\
\hline & $\begin{array}{l}\text { Private } \\
\text { sector }\end{array}$ & $\begin{array}{l}\text { Public } \\
\text { sector }\end{array}$ & $\begin{array}{l}\text { Diffe- } \\
\text { rence }\end{array}$ & $\begin{array}{l}\text { Private } \\
\text { sector }\end{array}$ & $\begin{array}{l}\text { Public } \\
\text { sector }\end{array}$ & $\begin{array}{l}\text { Diffe- } \\
\text { rence }\end{array}$ \\
\hline Useful to society & 17 & 22 & +5 & 15 & 32 & +17 \\
\hline $\begin{array}{l}\text { Allows someone to } \\
\text { help other } \\
\text { people }\end{array}$ & 19 & 22 & +3 & 18 & 27 & +9 \\
\hline Base & 623 & 282 & & 507 & 260 & \\
\hline
\end{tabular}

Note that the divergence is all down to a change in the attitudes of public sector employees - private sector employees have hardly changed their views at all. We now examine three possible reasons for this finding: a changing experience of work in the public sector, a changing composition of the public sector workforce, and a change in the nature of the young people entering the public service at the start of their careers.

\section{Changing experience of work?}

The first area to consider is people's actual experience of work. If, despite the New Labour reforms, those in the public sector are still more likely than those in the private sector to believe that their own job offers them the chance to do something useful for society or to help people, then it may help explain why we do not see the convergence we anticipated. It would not, however, explain the divergence we saw in the previous section.

One reason why public sector employees still believe their jobs to be more socially useful could be the massive expansion of the public sector under New Labour, after many years of reduction or constraint. New projects based on exciting ideas to combat public problems may have energised public sector workers and created a halo effect for those already in public sector employment. 
More generally, the public sector became less of a 'dirty word' and has been valued more in its own right.

We can test this directly, because in addition to asking respondents what was important in a job, we asked them whether they agreed with the following two statements:

In my job I can help other people

My job is useful to society

As the next table shows, there are striking differences between people in the two sectors, with those in the public sector considerably more likely to say their job is useful to society and allows them to help other people. That this is the case suggests that the changes in the organisation of the public sector have yet to be fully felt 'on the ground'. However, as the table also shows, the differences between the two sectors have not changed since 1997 and thus cannot help us to explain the increase in the public service ethos.

Table 5.4 Social usefulness of own job, private and public sector employees, 1997 and 2005

\begin{tabular}{lcccccc}
\hline $\begin{array}{l}\text { \% "strongly } \\
\text { agree" }\end{array}$ & $\begin{array}{c}\text { Private } \\
\text { sector }\end{array}$ & $\begin{array}{c}\text { Public } \\
\text { sector }\end{array}$ & $\begin{array}{c}\text { Diffe- } \\
\text { rence }\end{array}$ & $\begin{array}{c}\text { Private } \\
\text { sector }\end{array}$ & $\begin{array}{c}\text { Public } \\
\text { sector }\end{array}$ & $\begin{array}{c}\text { Diffe- } \\
\text { rence }\end{array}$ \\
$\begin{array}{l}\text { My job is useful to } \\
\text { society" }\end{array}$ & 9 & 42 & +33 & 14 & 45 & +31 \\
$\begin{array}{l}\text { "In my job I can } \\
\text { help other } \\
\text { people" }\end{array}$ & 11 & 39 & +28 & 17 & 44 & +27 \\
\begin{tabular}{l} 
Base \\
\hline
\end{tabular} & 336 & 142 & & 274 & 146 & \\
\hline
\end{tabular}

\section{Changing composition of the public sector?}

Another possible explanation for the increase in the public service ethos relates to the composition of the public sector. If the type of people working in the public sector has changed, in terms of either their socio-demographic characteristics or the type of work they undertake, then that might account for the change.

To take the latter point first, it could be the case that people working in particular fields have distinctive views regarding work and that during the course of Labour's modernisation programme these fields moved from the public to the private sector. So, for instance, those who were previously employed by the public sector but who we might not anticipate to have had such 
a distinctive public service ethos (for instance, cleaners or ancillary workers) could have moved into the private sector. This would then have had the effect of increasing the relative prevalence of the public service ethos among those left in the public sector.

We can test this by looking at the proportions of the public and private sectors employed in the major areas of occupation as measured by the Standard Industrial Classification (see Appendix I to this Report for more details on this), and how they vary in 1997 and 2005. But Table 5.5 shows that there have not been any shifts of a size that could reasonably be expected to account for the changes we have witnessed.

Table 5.5 Composition of the workforce by industrial classification, private and public sector employees, 1997 and 2005

\begin{tabular}{lcccccc}
\hline & \multicolumn{3}{c}{ Private sector } & \multicolumn{3}{c}{ Public sector } \\
& 1997 & 2005 & Change & 1997 & 2005 & Change \\
& $\%$ & $\%$ & & $\%$ & $\%$ & \\
Manufacturing & 36 & 27 & -9 & 1 & 2 & +1 \\
Construction & 4 & 5 & +1 & 4 & 1 & -3 \\
Wholesale, retail trade & 20 & 19 & -1 & 1 & 0 & -1 \\
Transport, storage, & 5 & 8 & +3 & 6 & 7 & +1 \\
$\quad$ communications & 9 & 11 & +2 & 4 & 2 & -2 \\
Real estate, renting & 0 & 1 & +1 & 24 & 25 & +1 \\
Public admin and defence & 2 & 2 & 0 & 25 & 29 & +4 \\
Education & 3 & 5 & +2 & 27 & 30 & +3 \\
Health and social work & & & & & & \\
Other social and personal & & & & & & \\
$\quad$ services & 4 & 5 & +1 & 3 & 2 & -1 \\
Base & 794 & 2404 & & 323 & 1158 & \\
\hline
\end{tabular}

Another reason for the overall change could be that the type of people working in the two sectors has changed. Perhaps socio-demographic groups with particularly distinctive views on work have changed their relative prevalence in the two sectors. To test this we need to examine whether people with particular socio-demographic characteristics have a distinctive public service ethos.

The next table shows the proportion of people in various social groups who think our two indicators of a public service ethos are "very important" in a job. Perhaps the most striking aspect of this table is how few differences there are. The only factor that was statistically significant on the question of a job being useful to society was education, with those with a degree or higher being much more likely than those with no qualifications to consider it to be "very 
important". On allowing someone to help other people the only factor that showed significant differences was whether people, were left wing or right wing, with those who are left wing more likely to think it very important. ${ }^{1}$ The implications of this being that even if the composition of the public sector has changed, these factors make little or no difference to the public service ethos.

Table 5.6 Importance of social usefulness in a job, by socio-demographics, 2005

\begin{tabular}{lcccc}
\hline & $\begin{array}{c}\text { \% say "very } \\
\text { important" for job to } \\
\text { be useful to society }\end{array}$ & \multicolumn{3}{c}{$\begin{array}{c}\text { Base } \\
\text { important" for job to } \\
\text { help other people }\end{array}$} \\
$18-34$ & 25 & 200 & 22 & 200 \\
$65+$ & 21 & 237 & 21 & 237 \\
Degree or higher & 29 & 269 & 25 & 269 \\
No qualifications & 17 & 234 & 19 & 234 \\
Professional/managerial & 23 & 342 & 22 & 342 \\
Routine/semi-routine & 19 & 247 & 20 & 247 \\
Male & 19 & 390 & 19 & 390 \\
Female & 22 & 523 & 23 & 523 \\
Highest income quartile & 22 & 161 & 21 & 161 \\
Lowest income quartile & 20 & 238 & 24 & 238 \\
Labour supporter & 23 & 379 & 21 & 379 \\
Conservative supporter & 19 & 243 & 25 & 243 \\
Left-wing & 23 & 314 & 25 & 314 \\
Right-wing & 20 & 320 & 18 & 320 \\
Trade union member & 25 & 150 & 21 & 150 \\
Not trade union member & 20 & 742 & 21 & 742 \\
\hline
\end{tabular}

\section{Changing entrants to the public sector?}

We have one more possible explanation for the increase in the public service ethos: with the changes that New Labour has embarked upon, perhaps different types of people are being attracted to the public sector in the first place. The public service ethos might be held more by young people choosing this as a career, showing that both the environment and the cohort effects are important. Increased public spending and new opportunities may have encouraged entry by public service-motivated individuals. Ironically, because the public and private sectors are now more similar in management-style, and given that the public 
sector tends to pay less, it is likely to be only those really committed to the public sector who join it. Before, those with a little less public service ethos might have been tempted to join the public sector, for example because they wanted more job security. Now, for those people, the distinction is perhaps so small that they might as well join the private sector where at least they will get paid more.

A related factor might be more general changes in views about politics among younger age groups. During the last 20 years there has been a massive drop-off in interest and participation in conventional politics by young people in the forms of party membership, voting, and trust in politics; but at the same time there has been an increase in social and issue awareness, such as over the environment, which has led to more interest in non-conventional forms of political activity (Russell et al., 2002). Perhaps a new idealism has fostered an interest in public sector work among some young people, perhaps as an alternative to the more 'selfish' careers in finance and management?

Table 5.7 Public service ethos, private and public sector, by age, 1997 and 2005

\begin{tabular}{|c|c|c|c|c|c|c|c|}
\hline & & 1997 & & & 2005 & & \\
\hline & $\begin{array}{l}\text { Private } \\
\text { sector }\end{array}$ & $\begin{array}{l}\text { Public } \\
\text { sector }\end{array}$ & $\begin{array}{l}\text { Diffe- } \\
\text { rence }\end{array}$ & $\begin{array}{l}\text { Private } \\
\text { sector }\end{array}$ & $\begin{array}{l}\text { Public } \\
\text { sector }\end{array}$ & $\begin{array}{l}\text { Diffe- } \\
\text { rence }\end{array}$ & $\begin{array}{c}\text { Change } \\
\text { in diffe- } \\
\text { rence }\end{array}$ \\
\hline \multicolumn{8}{|c|}{$\begin{array}{l}\text { \% say "very important" } \\
\text { that job is useful to } \\
\text { society }\end{array}$} \\
\hline $18-34$ & 16 & 28 & +12 & 19 & 49 & +30 & +18 \\
\hline Base & 223 & 48 & & 136 & 46 & & \\
\hline $35+$ & 17 & 22 & +5 & 13 & 28 & +15 & +10 \\
\hline Base & 623 & 282 & & 371 & 214 & & \\
\hline \multicolumn{8}{|c|}{$\begin{array}{l}\text { \% say "very important" } \\
\text { that job can help other } \\
\text { people }\end{array}$} \\
\hline $18-34$ & 15 & 24 & +9 & 18 & 39 & +21 & +12 \\
\hline Base & 223 & 48 & & 136 & 46 & & \\
\hline $35+$ & 19 & 22 & +3 & 17 & 24 & +7 & +4 \\
\hline Base & 623 & 282 & & 371 & 214 & & \\
\hline
\end{tabular}

Although the numbers in our samples are rather small, we can see in Table 5.7 that young people in public and private sector jobs have diverged to a greater extent than those aged 35 and over. For instance, among those aged 18-34 in 
1997, those working in the public sector were 12 percentage points more likely than those working in the private sector to think it very important that a job is useful to society, whereas amongst those aged over 35 the difference was five percentage points. By 2005, the public-private difference among the young had increased by 18 percentage points, compared to a 10 percentage point increase among the older age group. We see a similar pattern on our other question about a job that can help others: between 1997 and 2005 the differences between the public and private sector increased considerably more among the younger age group than the older one.

It is also interesting to compare younger and older age groups in terms of their experience of their own job. The next table shows considerable differences. On both questions the difference between the public and private sector among those aged between 18 and 34 has increased by more than 20 percentage points, whereas for those aged 35 and over, the difference has declined. The result is a quite startling difference between young public and private sector employees today - around two-thirds of young public sector employees now "strongly agree" that their job is useful to society and gives them the opportunity to help other people, compared with less than a fifth in the private sector who take this view.

Table 5.8 Social usefulness of own job, by private or public sector, by age, 1997 and 2005

\begin{tabular}{|c|c|c|c|c|c|c|c|}
\hline & & 1997 & & & 2005 & & \\
\hline & $\begin{array}{l}\text { Private } \\
\text { sector }\end{array}$ & $\begin{array}{l}\text { Public } \\
\text { sector }\end{array}$ & $\begin{array}{l}\text { Diffe- } \\
\text { rence }\end{array}$ & $\begin{array}{l}\text { Private } \\
\text { sector }\end{array}$ & $\begin{array}{l}\text { Public } \\
\text { sector }\end{array}$ & $\begin{array}{c}\text { Diffe- } \\
\text { erence }\end{array}$ & $\begin{array}{c}\text { Change } \\
\text { in diffe- } \\
\text { rence }\end{array}$ \\
\hline \multicolumn{8}{|c|}{$\begin{array}{l}\% \text { "strongly agree" own } \\
\text { job is useful to society }\end{array}$} \\
\hline $18-34$ & 8 & 36 & +28 & 14 & 65 & +51 & +23 \\
\hline Base & 155 & 39 & & 102 & 39 & & \\
\hline $35+$ & 9 & 42 & +33 & 15 & 34 & +19 & -14 \\
\hline Base & 336 & 142 & & 172 & 107 & & \\
\hline \multicolumn{8}{|c|}{$\begin{array}{l}\% \text { "strongly agree" own } \\
\text { job helpful to other } \\
\text { people }\end{array}$} \\
\hline $18-34$ & 13 & 33 & +20 & 19 & 63 & +44 & +24 \\
\hline Base & 155 & 39 & & 102 & 39 & & \\
\hline $35+$ & 11 & 39 & +28 & 16 & 36 & +20 & -8 \\
\hline Base & 336 & 142 & & 172 & 107 & & \\
\hline
\end{tabular}




\section{What does it mean to have a public service ethos?}

\section{The broader context of the public service ethos}

So far we have examined a rather narrow definition of public service ethos based on a desire to have a socially useful job. What does it mean to the person's broader view of work? There are other measures we can employ which are representative of something we term 'altruistic motivations' when it comes to work. For example, respondents were asked how much they agreed with the following two statements when thinking of work in general:

\section{A job is just a way of earning money - no more}

I would enjoy having a paid job even if I did not need the money

Given our conceptualisation of what a public service ethos is, namely that public sector workers are more altruistic, we would anticipate that those in the public sector would be more likely than those in the private sector to disagree with the first statement and more likely to agree with the second. Our analysis shows that this is indeed the case. Twice as many of those in the public sector strongly disagreed that a job is just a way of earning money (17 per cent compared to eight per cent), and significantly more strongly agreed that they would enjoy a job even if they did not need the money (12 per cent compared to seven per cent). And as Table 5.9 shows, the differences between public and private sector workers appears to be increasing over time.

Table 5.9 Broader public service ethos (i), private and public sector employees, 1997 and 2005

\begin{tabular}{lcccccc}
\hline & $\begin{array}{c}1997 \\
\text { Private } \\
\text { sector }\end{array}$ & $\begin{array}{c}\text { Public } \\
\text { sector }\end{array}$ & $\begin{array}{c}\text { Diffe- } \\
\text { rence }\end{array}$ & $\begin{array}{c}\text { Private } \\
\text { sector }\end{array}$ & $\begin{array}{c}\text { Public } \\
\text { sector }\end{array}$ & $\begin{array}{c}\text { Diffe- } \\
\text { rence }\end{array}$ \\
$\begin{array}{l}\% \text { "strongly disagree" a } \\
\text { job just a way to earn }\end{array}$ & 9 & 14 & +5 & 8 & 17 & +9 \\
$\begin{array}{l}\text { money } \\
\% \text { "strongly agree" would } \\
\text { enjoy job even if didn't } \\
\text { need money }\end{array}$ & 7 & 7 & 0 & 7 & 12 & +5 \\
Base & 623 & 282 & & 507 & 260 & \\
\hline
\end{tabular}

We might also anticipate that those in the public sector would be more committed and proud to work for their organisation than those in the private sector, on the basis that doing a wider public good feeds into organisational 
loyalty. In addition, those in the public sector might be expected to be loyal and prepared to carry on working for less pay than elsewhere. We have three questions that allow us to assess this aspect, where people were asked the extent to which they agreed with each of the following statements:

I am willing to work harder than I have to in order to help the firm or organisation I work for succeed

I am proud to be working for my firm or organisation

I would turn down another job that offered quite a bit more pay in order to stay with this organisation

Here we see a somewhat more mixed picture. Only on the second statement are those in the public sector more likely to strongly agree, whereas there are no differences on either of the other two statements. And, indeed, it is only on the second one that there has been any change over time, with the difference between the two sectors again increasing.

Table 5.10 Broader public service ethos (ii), private and public sector employees, 1997 and 2005

\begin{tabular}{|c|c|c|c|c|c|c|}
\hline \multirow[b]{2}{*}{$\begin{array}{l}\% \text { "strongly agree" } \\
\text { that ... }\end{array}$} & \multicolumn{3}{|c|}{1997} & \multicolumn{3}{|c|}{2005} \\
\hline & $\begin{array}{l}\text { Private } \\
\text { sector }\end{array}$ & $\begin{array}{l}\text { Public } \\
\text { sector }\end{array}$ & $\begin{array}{l}\text { Diffe- } \\
\text { rence }\end{array}$ & $\begin{array}{l}\text { Private } \\
\text { sector }\end{array}$ & $\begin{array}{l}\text { Public } \\
\text { sector }\end{array}$ & $\begin{array}{l}\text { Diffe- } \\
\text { rence }\end{array}$ \\
\hline $\begin{array}{l}\ldots \text { willing to work harder } \\
\text { than have to }\end{array}$ & 13 & 12 & -1 & 18 & 15 & -3 \\
\hline $\begin{array}{l}\text {... proud to be working } \\
\text { for firm/organisation }\end{array}$ & 10 & 13 & +3 & 14 & 23 & +9 \\
\hline $\begin{array}{l}\ldots \text { turn down job with } \\
\text { more pay to stay }\end{array}$ & 4 & 6 & +2 & 6 & 3 & -3 \\
\hline Base & 336 & 142 & & 274 & 146 & \\
\hline
\end{tabular}

A further line of argument concerns the identities of people in the two sectors. People were asked:

Thinking now not just of your own workplace but more generally, how much do you feel you have in common with people who do this job, compared with other people?

A lot more in common with them than with other people A little more in common with them than with other people No more in common with them than with other people 
Whilst this question does not specifically ask about identity with people in the same sector as the respondent, it is interesting to observe that those in the public sector seem to identify to a greater extent with people doing similar jobs to them. In the public sector 37 per cent felt they had a lot more in common with them than with other people, compared with only 24 per cent taking that view in the private sector. There seems therefore to be greater solidarity in the public sector.

In conclusion, then, we can see that working in the public sector is related to a wider set of values than purely the public service ethos of wanting to do a socially useful job. In particular, it seems to be related to a more general belief in the importance of work, a pride in the organisation and a feeling of having something in common with colleagues. How far this can stretch is a moot point - not as far as working harder than you have to or turning down a job with more pay, apparently.

\section{What does a public service ethos mean for job satisfaction?}

Do those endowed with a public service ethos have more job satisfaction? After all, if people have this wider set of values and the public sector delivers on helping them realise those, they should be more satisfied than equivalent private sector workers. They might be able to deal with the frustration of working life more effectively than someone who is just there for the money (though it is possible that people may become more dissatisfied if their expectations are higher but they fail to meet them). We asked respondents:

\section{All in all, how satisfied are you with your main job?}

Some 42 per cent of those in the public sector were very satisfied, whilst only 35 per cent of those in the private sector were.

Further, those with a particularly strong public service ethos were significantly more likely to have high job satisfaction. Table 5.11 shows the proportion of people very satisfied with their job broken down by their views on the importance of different aspects of a job. Those people who think it is "very important" that a job is useful to society were 17 percentage points more likely to be very satisfied with their job than those who did not take such a view. This difference was even higher when the importance of a job allowing someone to help other people was considered.

Table 5.11 also shows how job satisfaction is strongly related to the extent to which people believe their own job is useful to society and allows them to help other people. Those who think their job means they can be useful to society are 30 percentage points more likely to be very satisfied. And those who felt their job allowed them to help other people were 29 percentage points more likely to be very satisfied. 
Table 5.11 Job satisfaction, by the public service ethos, 2005

\begin{tabular}{|c|c|c|}
\hline & $\%$ "very satisfied" with their job & Base \\
\hline \multicolumn{3}{|c|}{$\begin{array}{l}\text { Importance that job is useful to } \\
\text { society }\end{array}$} \\
\hline "Very important" & 55 & 84 \\
\hline Not "very important" & 38 & 329 \\
\hline Difference & +17 & \\
\hline \multicolumn{3}{|c|}{$\begin{array}{l}\text { Importance that job allows helping } \\
\text { other people }\end{array}$} \\
\hline "Very important" & 57 & 91 \\
\hline Not "very important" & 37 & 322 \\
\hline Difference & +20 & \\
\hline \multicolumn{3}{|c|}{ Own job is useful to society } \\
\hline "Strongly agree" & 64 & 106 \\
\hline Not "strongly agree" & 34 & 302 \\
\hline Difference & +30 & \\
\hline \multicolumn{3}{|c|}{$\begin{array}{l}\text { Own job allows helping other } \\
\text { people }\end{array}$} \\
\hline "Strongly agree" & 63 & 109 \\
\hline Not "strongly agree" & 34 & 299 \\
\hline Difference & +29 & \\
\hline
\end{tabular}

To understand what is driving these differences we need to control for other potentially confounding factors. When we carry out a multivariate analysis to control for these factors, we find that having a socially useful job tends to improve it (see the appendix to this chapter for full details of this analysis). Thus the public service ethos may indeed go some way to compensate for the lower levels of remuneration and worse working conditions. This kind of compensation is at the core of the public service ethos agenda - and why it is possible to be cynical about official attempts to improve it.

\section{Conclusions}

The public service ethos is an important dimension to job motivation which can help to compensate for lower rates of pay and poorer working conditions in the public sector. It has been heralded by reformers as a key to public service performance, and many writers claim that has been neglected by the policies inspired by private sector management, such as contracting out, quasi markets 
and choice. The argument is that if public sector employers treat their employees as self-interested actors motivated by performance-related pay and punished by failure to meet targets, they will, in turn, behave in a strategic and egoistical fashion so eroding the public service ethos and with it the distinctive contribution of the public sector to the welfare of society at large. But these data paint a different picture: the public service ethos appears to have increased rather than withered during the New Labour years. It would seem that private sector forms of management are not necessarily incompatible with sustaining the public service ethos. The predictions of decline based on the rise of individual self-interest are not borne out by this data.

It is not easy to identify the reasons for the rise in the public service ethos, but it is clear that there is something special about the young people entering public service today. It may be that, as the public sector becomes more like the private sector, the choice of careers becomes one of values rather than, for example, job security, so that the public sector ends up attracting only those who are already committed to it. It may also be a reflection of value change among younger generations: a more issue-based cohort may be as ready to work in the public sector as to travel on an environmental gap year or to boycott certain products.

For public sector reformers, these findings do not appear to justify a roll back to a more collectivist form of public sector organisation, or suggest a rejection of the New Labour reforms - at least on public service ethos grounds. The main challenge is how to sustain these values in a period when public spending does not increase at the same rate as before. It also has to be recognised that there are limits to what a public service ethos will achieve: job security is almost as important as an interesting job, even for public sector workers, and the public service ethos will not necessarily make people work harder than they have to or turn down another job with more pay. The public service ethos cannot be expected to compensate for all sources of job dissatisfaction in the public sector. The danger is that continuing poorer working conditions and worse rates of pay will over time erode these public-minded values, particularly among new entrants.

\section{Notes}

1. Respondents were categorised as left-wing or right-wing using their score on the left-right scale (see Appendix I of this Report for further details).

\section{References}

Allington, N. and Morgan, P. (2003), 'Does it pay to work in the private sector? Evidence from three decades of econometric analysis', Public Money and Management, October: 253-262 
Boyne, G. (2002), 'Public and Private Management: What's the difference?', Journal of Management Studies, 39(1): 97-122

Buelens, M. and Broeck, van den H. (2007), 'An analysis of differences in work motivation between public and private sector organizations', Public Management Review, 67:65-74

Crewson, P. (1995), 'A comparative analysis of public and private sector entrant quality', American Journal of Political Science, 39(3): 628-639

Crewson, P. (1997), 'Public service motivation: building empirical evidence of incidence and effect', Journal of Public Administration Research and Theory, 7(4): 499-518

DeHart-Davis, L., Marlowe, J. and Pandey, S. (2006), 'Gender dimensions of public service motivation', Public Administration Review, 66: 873-887

Houston, D. (2000), 'Public service motivation: a multivariate test', Journal of Public Administration Research and Theory, 10(4): 713-727

Jurkiewicz, C. and Brown, R. (1998), 'Generational comparisons of public employee motivation', Review of Public Personnel Administration, 18: 18-37

Le Grand, J. (2003), Motivation, Agency and Public Policy: Of Knights and Knaves, Pawns and Queens, Oxford: Oxford University Press

Norris, P. (2003), 'Still a public service ethos? Work values, experience and job satisfaction amongst government workers', unpublished paper downloadable from www.pippanorris.com

Plant, R. (2003), 'A public service ethos and political accountability', Parliamentary Affairs, 56: 560-579

Pratchett, L. and Wingfield, M. (1996), 'Petty bureaucracy and woolly minded liberalism? The changing ethos of UK local government officers', Public Administration, 74(4): 639-656

Public Administration Committee (2002), Seventh Report, The Public Service Ethos, London: HMSO

Public Services Productivity Panel (2002), Making A Difference: Motivating People to Improve Performance, London: HM Treasury

Rainey, H.G. (1982), 'Reward preferences among public and private managers: in search of the service ethic', American Review of Public Administration, 16: 88-302

Rainey, H. and Bozeman, B. (2000), 'Comparing public and private organizations: empirical research and the power of the a priori', Journal of Public Administration Research and Theory, 10: 447-470

Russell, A., Fieldhouse, E., Purdam, K. and Kalra, V. (2002), Voter engagement and young people, London: The Electoral Commission

Steele, J. (1999), Wasted Values - Harnessing the Commitment of Public Managers, London: Public Management Foundation

Wittmer, D. (1991), 'Serving the people or serving for pay: reward preferences among government, hybrid sector, and business managers', Public Productivity and Management Review, 14(4): 369-83 


\section{Acknowledgements}

The National Centre for Social Research is grateful to the Economic and Social Research Council (grant number RES 50125 5001) for the financial support which enabled us to ask the questions reported in this chapter. The views expressed are those of the authors alone. 


\section{Appendix}

The multivariate analysis technique used in this chapter was ordered probit regressions. Ordered probit is needed because the dependent variable is ordinal.

\section{Table A.1 Predictors of public service ethos}

\begin{tabular}{|c|c|c|c|c|}
\hline & \multicolumn{2}{|c|}{$\begin{array}{l}\text { "Very important" that job } \\
\text { helps other people }\end{array}$} & \multicolumn{2}{|c|}{$\begin{array}{l}\text { "Very important" that job is } \\
\text { useful to society }\end{array}$} \\
\hline & Coefficient & $\begin{array}{l}\text { Standard } \\
\text { error }\end{array}$ & Coefficient & $\begin{array}{l}\text { Standard } \\
\text { error }\end{array}$ \\
\hline $18-34$ & 0.118 & 0.18 & -0.113 & 0.18 \\
\hline $65+$ & 0.00946 & 0.11 & 0.18 & 0.11 \\
\hline Degree or higher & 0.0651 & 0.12 & -0.0276 & 0.12 \\
\hline No qualifications & 0.00795 & $(0.12)$ & 0.0245 & 0.12 \\
\hline Professional/managerial & $-0.183^{*}$ & 0.10 & -0.146 & 0.10 \\
\hline Routine/semi-routine & -0.164 & 0.11 & -0.0559 & 0.10 \\
\hline Female & $0.149^{*}$ & 0.085 & $0.333^{* * *}$ & 0.086 \\
\hline Lowest income quartile & 0.0272 & 0.12 & 0.147 & 0.12 \\
\hline Highest income quartile & -0.0261 & 0.11 & 0.0412 & 0.11 \\
\hline Labour supporter & -0.0535 & 0.099 & -0.0162 & 0.099 \\
\hline Conservative supporter & -0.0898 & 0.12 & 0.116 & 0.12 \\
\hline Left-right scale & $-0.150^{* *}$ & 0.063 & $-0.158^{* *}$ & 0.063 \\
\hline Trade union member & 0.00116 & 0.060 & 0.0278 & 0.060 \\
\hline Public sector & $0.403^{* * *}$ & 0.100 & $0.255^{* *}$ & 0.100 \\
\hline Cut 1 & $-2.629^{* \ldots k}$ & 0.30 & $-2.370^{* * \star}$ & $0.31^{\circ}$ \\
\hline Cut 2 & $-1.806^{* * *}$ & 0.27 & $-1.479^{* * *}$ & 0.27 \\
\hline Cut 3 & $-0.650^{* *}$ & 0.26 & -0.348 & 0.26 \\
\hline Cut 4 & $0.669^{* *}$ & .2 & $1.102^{* \star *}$ & 0.26 \\
\hline $\mathrm{N}$ & 706 & & 713 & \\
\hline Pseudo rsq & .02 & & .02 & \\
\hline
\end{tabular}

* = significant at $5 \%$ level

** $=$ significant at $1 \%$ level

$* * *=$ significant at $0.1 \%$ level 
Table A.2 Predictors of job satisfaction

\begin{tabular}{|c|c|c|c|c|}
\hline & \multicolumn{2}{|c|}{ Model 1} & \multicolumn{2}{|c|}{ Model 2} \\
\hline & Coefficient & $\begin{array}{l}\text { Standard } \\
\text { error }\end{array}$ & Coefficient & $\begin{array}{c}\text { Standard } \\
\text { error }\end{array}$ \\
\hline $18-34$ & -0.149 & 0.23 & -0.0804 & 0.23 \\
\hline $65+$ & 0.546 & 0.56 & 0.377 & 0.56 \\
\hline Degree or higher & -0.200 & 0.15 & -0.189 & 0.15 \\
\hline No qualifications & -0.133 & 0.20 & -0.113 & 0.20 \\
\hline Profess/managerial & -0.237 & 0.16 & -0.239 & 0.16 \\
\hline Routine/semi routine & -0.160 & 0.18 & -0.180 & 0.17 \\
\hline Female & $0.246^{* *}$ & 0.12 & 0.192 & 0.12 \\
\hline Lowest income quartile & -0.345 & 0.29 & -0.454 & 0.29 \\
\hline Highest income quartile & $0.314^{* *}$ & 0.14 & $0.316^{\star *}$ & 0.14 \\
\hline Trade Union member & $0.228^{\star \star *}$ & 0.076 & $0.249^{* * *}$ & 0.075 \\
\hline Public sector & 0.198 & 0.15 & $0.247^{*}$ & 0.15 \\
\hline Job useful to society & $0.127^{*}$ & 0.076 & & \\
\hline Job helps other people & & & $0.197^{* *}$ & 0.077 \\
\hline Cut 1 & -0.61 & 0.42 & -0.338 & $0.41^{-}$ \\
\hline Cut 2 & -0.102 & 0.41 & 0.158 & 0.42 \\
\hline Cut 3 & 0.314 & 0.41 & 0.570 & 0.42 \\
\hline Cut 4 & $1.623^{* * *}$ & 0.41 & $1.885^{\star \star \star}$ & 0.41 \\
\hline Pseudo R2 & .03 & & .04 & \\
\hline $\mathrm{N}$ & 348 & & 352 & \\
\hline
\end{tabular}

* = significant at $5 \%$ level

** $=$ significant at $1 \%$ level

${ }^{* * *}=$ significant at $0.1 \%$ level 
